Erratum doi: 10.1007/s00376-012-0001-y

\title{
Erratum to: Radiative Forcing and Climate Response Due to Black Carbon in Snow and Ice
}

\author{
WANG Zhili ${ }^{1,2,3}$ (王志立), ZHANG Hua ${ }^{3}$ (张 华), and SHEN Xueshun ${ }^{4}$ (沈学顺) \\ ${ }^{1}$ Center for Atmosphere Watch and Services, Chinese Academy of Meteorological Sciences, \\ China Meteorological Administration, Beijing 100081 \\ ${ }^{2}$ Graduate University of Chinese Academy of Sciences, Beijing 100049 \\ ${ }^{3}$ National Climate Center, China Meteorological Administration, Beijing 100081 \\ ${ }^{4}$ State Key Laboratory of Severe Weather, \\ Chinese Academy of Meteorological Sciences, Beijing 100081
}

Erratum to: Wang, Z. L., H. Zhang, and X. S. Shen, 2011: Radiative forcing and climate response due to black carbon in snow and ice. Adv. Atmos. Sci., 28(6), 1336-1344, doi: 10.1007/s00376-011-0117-5.

In the original version of this article, wrong statistics in the column "Surface radiative forcing $\left(\mathrm{W} \mathrm{m}^{-2}\right)$ " were provided. The correct Table 1 is shown below.

Table 1. Global and regional climate responses to BC in snow/ice.

\begin{tabular}{llllll}
\hline & $\begin{array}{l}\text { Surface radiative } \\
\text { forcing } \\
\left(\mathrm{W} \mathrm{m} \mathrm{m}^{-2}\right)\end{array}$ & $\begin{array}{l}\text { Surface } \\
\text { temperature } \\
\left({ }^{\circ} \mathrm{C}\right)\end{array}$ & $\begin{array}{l}\text { Snow cover } \\
\text { ratio } \\
\left(10^{-3}\right)\end{array}$ & $\begin{array}{l}\text { Snow } \\
\text { depth } \\
(\mathrm{mm})\end{array}$ & $\begin{array}{l}\text { Ice amount } \\
\text { on land } \\
\left(\mathrm{kg} \mathrm{m}^{-2}\right)\end{array}$ \\
\hline $\begin{array}{l}\text { Eurasia } \\
\begin{array}{l}\text { North } \\
\text { America }\end{array}\end{array}$ & $0.71 / 1.13 / 0.52$ & $0.83 / 0.60 / 0.39$ & $-18.2 /-26.2 /-15.7$ & $12.6 /-19.9 /-13.6$ & $-3.86 /-8.02 /-5.13$ \\
Global & $0.028 / 0.13 / 0.042$ & $0.094 / 0.089 / 0.071$ & $-6.70 /-8.65 /-7.39$ & $-8.91 /-12.6 /-10.7$ & $-9.97 /-14.5 /-10.7$ \\
\hline
\end{tabular}

Note: *The three values represent the winter and spring seasons and the annual mean changes of these physical variables, respectively. The geographic ranges for Eurasia and North America are $\left(30^{\circ}-70^{\circ} \mathrm{N}, 20^{\circ}-130^{\circ} \mathrm{E}\right)$ and $\left(30^{\circ}-70^{\circ} \mathrm{N}, 60^{\circ}-130^{\circ} \mathrm{W}\right)$, respectively.

The online version of this original article can be found at http://dx.doi.org/10.1007/s00376-011-0117-5

(C) China National Committee for International Association of Meteorology and Atmospheric Sciences (IAMAS), Institute of Atmospheric Physics (IAP) and Science Press and Springer-Verlag Berlin Heidelberg 2012 